\title{
LLC Resonant Tank based Converter for EV Charging Application
}

\author{
S. Nagaraj, R. Ranihemamalini, L. Rajaji, K. Srividya, A. Mohandoss
}

\begin{abstract}
The aim of the article is to maximize the battery life using LLC resonant tank. LLC tank designing methodology and also the practical designing examination is introduced in $L L C$ multi converter. Designed dc- dc converter increases the battery life by eliminating low and high frequency current ripples. In addition, bridgeless cuk converter is used for power factor improvement. To achieve the better power factor and to reduce the conduction losses the cuk converter is aimed to function in discontinuous mode of conduction (DCM). DC output voltage ranging 42-24 $\mathrm{V}$ for $650 \mathrm{~W}$ is obtained from the modelling for battery charging application.
\end{abstract}

Keywords: Discontinuous conduction mode (DCM), LLC multi resonant converter, Bridgeless cuk converter.

\section{INTRODUCTION}

Rechargeable battery supplies power to electric motor to drive electric vehicle [1],[2]. Currently, the standard battery systems storage capability demand is increased. Even though battery technology is improved, the system requires high current and high voltage to charge these batteries. Nowadays the smart charger battery charging methodology becomes very difficult due to the advancement in charging algorithms [3]. A smart charger with low distortion is required because of increased disturbances in quick charging of excessive potential of battery packs. The proposed architecture block includes a bridgeless cuk converter, followed by a resonant converter as depicted in Fig. 1 which rejects the current ripple charging energy storage system i.e., battery using a high frequency transformer.

The criterion for selecting discontinuous conduction mode topology includes natural protection against overload current, easy implementation of transformer isolation and less electromagnetic interference. Second section describes about

Revised Manuscript Received on February 05, 2020.

* Correspondence Author

S. Nagaraj*, Research Scholar, Department of EEE, St. Peter's Institute of Higher Education and Research, Avadi, Chennai, India.

E-mail: nagarajsubramani11@gmail.com

Dr. R. Ranihemamalini , Professor and Head, Department of EEE, St. Peter's Institute of Higher Education and Research, Avadi, Chennai, India. E-mail: ranihema69@gmail.com

Dr. L. Rajaji, Principal, ARM College of Engineering and Technology, Maraimalai nagar, Chennai, India, E-mail : rajajiloganathan@gmail.com

K. Srividya , Assistant Professor, Department of EI , Sri Sairam Engineering College, West Tambaram, Chennai, India,

E-mail: ksrividya2005@gmail.com

A. Mohandoss , Assistant Professor, Department of EEE, P. B. College of Engineering, Chennai, India, E-mail: mohandass321@gmail.com

(C) The Authors. Published by Blue Eyes Intelligence Engineering and Sciences Publication (BEIESP). This is an open access article under the CC BY-NC-ND license (http://creativecommons.org/licenses/by-nc-nd/4.0/) chopper representing multi - resonant half - bridge power converter. Though, the battery charger's wide output voltage specifications are extremely challenging and varying while comparing to telecom applications that operates in a narrowed. DC-DC converter battery output voltage varies from $36 \mathrm{~V}$ to $72 \mathrm{~V}$. Hence the designing specifications to choose the bridgeless cuk converter and LLC components are non- identical suits for telecommunication application under continuous voltage. LLC resonant tank converter is required to meet these specifications. To achieve high switching frequency and higher efficiency resonant tank is modeled for higher range of input voltage. Both zero voltage and zero current switching are achievable over the entire operating range. Chapter 2 tells about the working of bridgeless cuk converter. Chapter 3 follows the design of cuk converter and multi resonant LLC converter. Chapter 4 gives the simulation results. Chapter 5 shows the hardware results. Chapter 6 gives the conclusion.

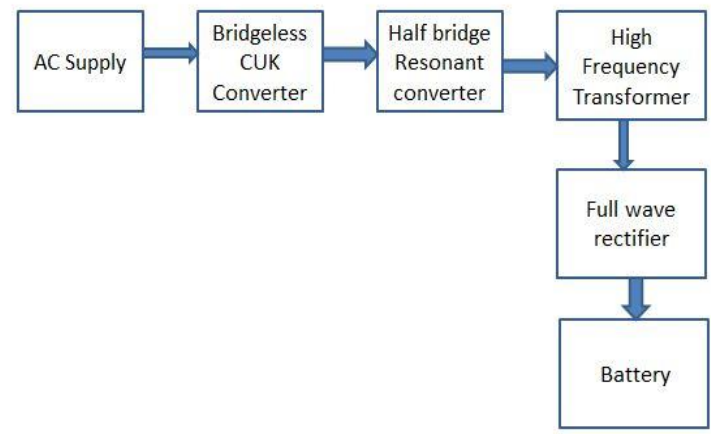

Fig. 1. Block Diagram of Proposed converter

\section{BRIDGELESS CUK DC/DC CONVERTER}

\section{A. Proposed System}

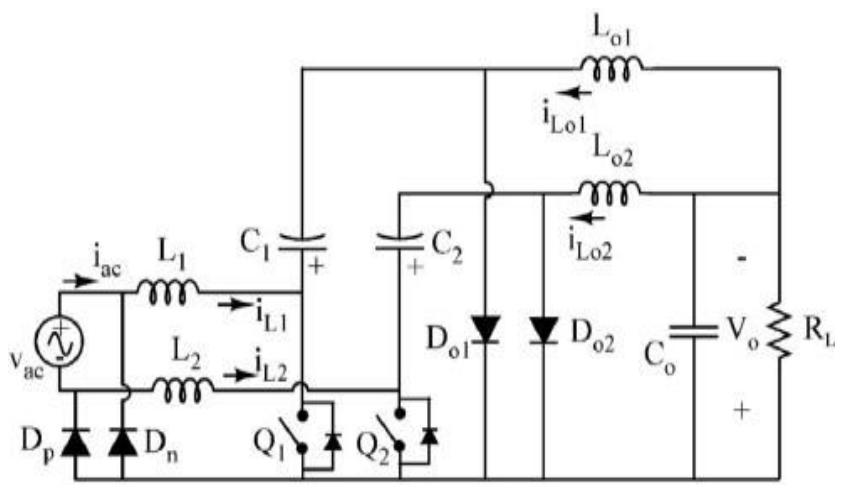

Fig.2. Bridgeless CUK Converter 


\section{LLC Resonant Tank based Converter for EV Charging Application}

The operation of the system under study is as shown in Fig 2 is described. For attaining PFC, the inductor output current inductor $\mathrm{i}_{\mathrm{L}} \mathrm{O} 1$ and $\mathrm{i}_{\mathrm{L}} \mathrm{O} 2$ remains discontinuous while the input inductor current (iL1 and iL2) and the voltage across intermediate capacitors remains continuous.

Mode I: While $S_{1}$ is at first made on, the $L_{01}$ stores energy through $\mathrm{D}_{\mathrm{p}}$ diode, hence the current $\mathrm{i}_{\mathrm{L} 1}$ through the inductor rises. Mode II: While $\mathrm{S}_{1}$ is made off, $\mathrm{i}_{\mathrm{L} 1}$ inductor that discharging across the $C_{1}$ capacitor through $\mathrm{D}_{1}$ and $\mathrm{D}_{\mathrm{p}}$ diodes. Also, $\mathrm{L}_{01}$ inductor's stored energy is transferred to $\mathrm{C}_{0}$ capacitor across DC-link. $\mathrm{i}_{\mathrm{L} 1}$ and $\mathrm{i}_{\mathrm{Lo1}}$ currents across the inductors will start to degrade whereas the voltage across $\mathrm{C}_{0}$ DC-link capacitor and $\mathrm{C}_{1}$ capacitor rises. Mode III: In this mode, $\mathrm{i}_{\mathrm{L} 01}$ inductor's current is zero. The capacitor $\mathrm{C}_{1}$ voltage increases through inductor L1.

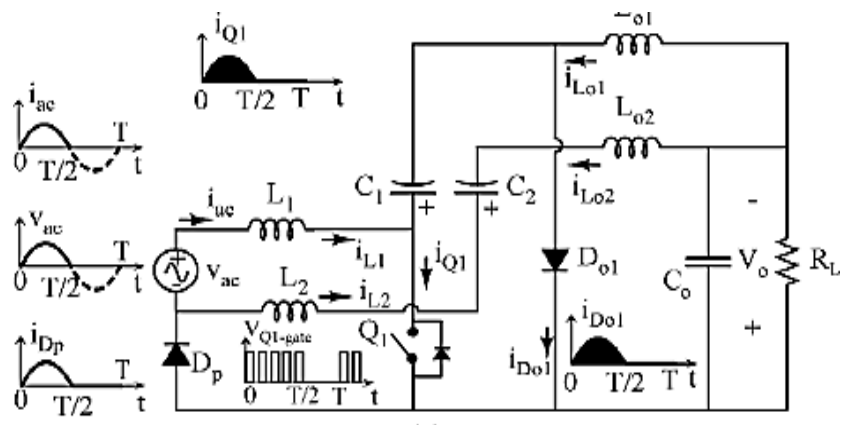

(a)

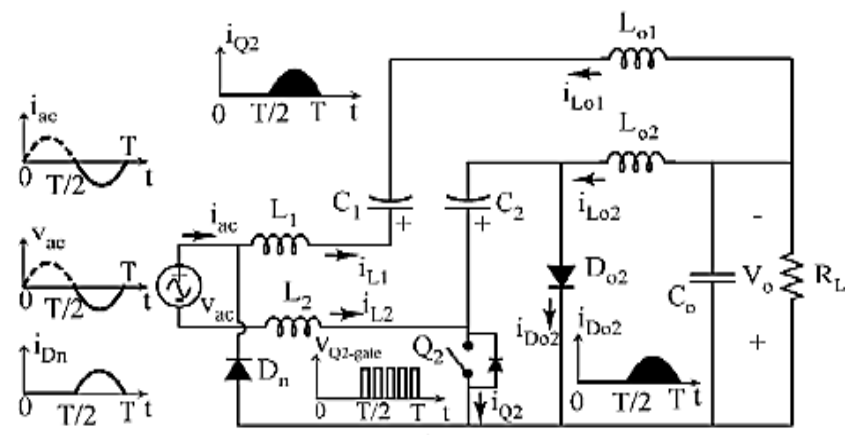

(b)

Fig.3. Equivalent circuit of proposed method

Fig. 3 depicts the working principle of system for both half cycles of the alternating current supply. Through the (+ve) period of the cycle of the AC voltage $V_{a c}, S 1$ switch is in conduction through $\mathrm{i}_{\mathrm{L} 1}$ and Dp. The capacitor C1 transfers energy over $L_{01}$ and $D_{01}$. Likewise, for (-ve) period of the cycle of AC voltage, $S_{2}$ switch is conducting over $i_{L 2}$ and $D_{n}$. Different modes of operation of cuk converter during positive half cycle is given by Mode I: While $S_{1}$ is at first made on, the $L_{01}$ stores energy through $D_{p}$ diode, hence the current $i_{L 1}$ through the inductor rises. The stored energy in $C_{1}$ capacitor present intermediate is discharged to $\mathrm{C}_{0}$, DC link capacitor and $\mathrm{L}_{\mathrm{o1}}$, output inductor. As a result, $\mathrm{i}_{\mathrm{Lo1}}$ and $\mathrm{V}_{\mathrm{dc}}$, voltage across the DC-link are increasing and $V_{C 1}$, voltage arises in the capacitor present intermediately reduces and $\mathrm{i}_{\mathrm{L} 1}$ current in rises, however the $\mathrm{C}_{0}$ capacitor across the DC-link delivers the necessary energy, hence there is a reduction of $\mathrm{V}_{\mathrm{dc}}$ voltage appears in mode III operation.

\section{DESIGN OF CONVERTER}

\section{A.Design of bridgeless cuk converter}

The design of the converter is framed under certain mathematical presumption. The operation of a DCM is acquired under the following condition.

$$
\mathrm{Ke}<\mathrm{Ke}_{\text {crit }}=\frac{1}{2(\mathrm{M}+\sin (\omega t))^{2}}
$$

Where, Ke is a dimensionless conduction parameter and is given by:

$$
\begin{gathered}
\mathrm{Ke}=\frac{2 \mathrm{Le}}{\mathrm{R}_{\mathrm{L}} \mathrm{Ts}} \\
\mathrm{K}_{\mathrm{e}-\mathrm{cr}-\min }=\frac{1}{2(\mathrm{M}+1)^{2}} \text { and } \mathrm{K}_{\mathrm{e}-\text { crit-min }} \frac{1}{2\left(\mathrm{MD}^{2}\right.}
\end{gathered}
$$

$\Delta \mathrm{i}_{\mathrm{L} 1}<10 \% \mathrm{I}_{\mathrm{L} 1}$ and $\Delta \mathrm{V}_{\mathrm{c} 1}<5 \%$

$\Delta \mathrm{I}_{\mathrm{L} 1}=\frac{\text { D.Vin }}{\mathrm{F}_{\mathrm{S}} \cdot \mathrm{L} 1 \mathrm{I}}$

$\Delta \mathrm{I}_{\mathrm{L} 2}=\frac{(1-\mathrm{D}) \cdot \mathrm{W}_{0}}{\mathrm{~F}_{\mathrm{S}} \cdot \mathrm{L} 2 \mathrm{~T}}$

$\Delta \mathrm{V}_{\mathrm{C} 1}=\frac{\mathrm{D}_{\mathrm{B}} \mathrm{V}_{\mathrm{d}} \cdot \mathrm{I}_{\mathrm{a}}}{\mathrm{V} \cdot \mathrm{C} \cdot \mathrm{F}_{\mathrm{S}}}$

From the equations (5), (6), (7) the values of inductances and capacitances are given by:

$$
\begin{aligned}
& \mathrm{L}_{1}=\quad \mathrm{L}_{2}=300 \mathrm{mH}, \quad \mathrm{L}_{01}=\mathrm{L}_{02}=1 \mathrm{mH}, \quad \mathrm{C}_{1}=\mathrm{C}_{2}=2200 \mu \mathrm{F}, \\
& \mathrm{C}_{\text {out }}=2200 \mu \mathrm{F} .
\end{aligned}
$$

The DC link voltage is given in equation (8).

$\mathrm{V}_{\mathrm{o}}=\mathrm{V}_{\mathrm{ac}} \frac{\mathrm{D}}{(\mathbb{1}-\mathrm{D})}$

Vac is the diode bridge rectifier output for a given AC input voltage (Vs).

Vac and Vs are related as:

$$
\mathrm{V}_{\mathrm{ac}}=2 \sqrt{2} \frac{\mathrm{Vs}}{\pi}
$$

\section{B. Design of Resonant Converter}

The parameter required to design the converter are to be specified. The parameters like maximum output power, input voltage range, resonant frequency and output voltage range are to be cited. At DC link capacitor using PFC bus the dc-dc input voltage is determined. The dc-dc output voltage range will vary from 24 to $43 \mathrm{~V}$. The existing output voltage $43 \mathrm{v}$ is described for the maximum power of $650 \mathrm{~W}$. The LLC resonant equivalent circuit is shown in figure 4. 


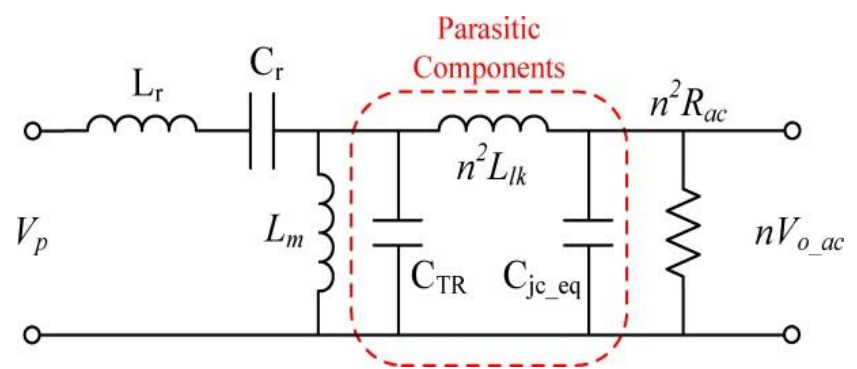

Fig.4. LLC resonant converter equivalent circuit
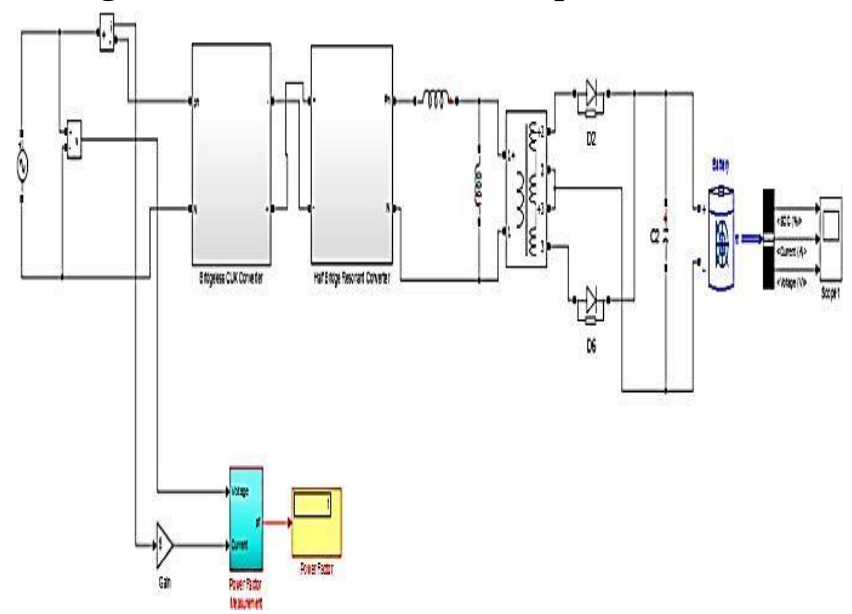

Fig.5. proposed Simulation Circuit

In Figure.5 it shows the complete MATLAB Simulation circuit of Proposed Converter. At unity gain, the TTR for the resonant frequency is selected and it is calculated using Equation 10, where $\mathrm{V}_{\mathrm{d}}$ denotes the rectifier's diode output voltage drop

$\mathrm{Nn}=\frac{\operatorname{Vin}(\text { nom })}{2(\operatorname{Vo}(\min )+V d)}$

The minimum inductance is given by Equation 11

$\operatorname{Lr}(\mathrm{scc})=\frac{\operatorname{Nn} \cdot \operatorname{Vin}(\mathrm{nom}) \cdot \operatorname{Vo}(\text { nom })}{\text { 8.fs_max.Po }}$

Resonant capacitor value is given by equation (12)

$\operatorname{Cr}(\mathrm{res})=\frac{1}{(2 \pi \mathrm{fo}) 2 \operatorname{Lr}(s C C)}$
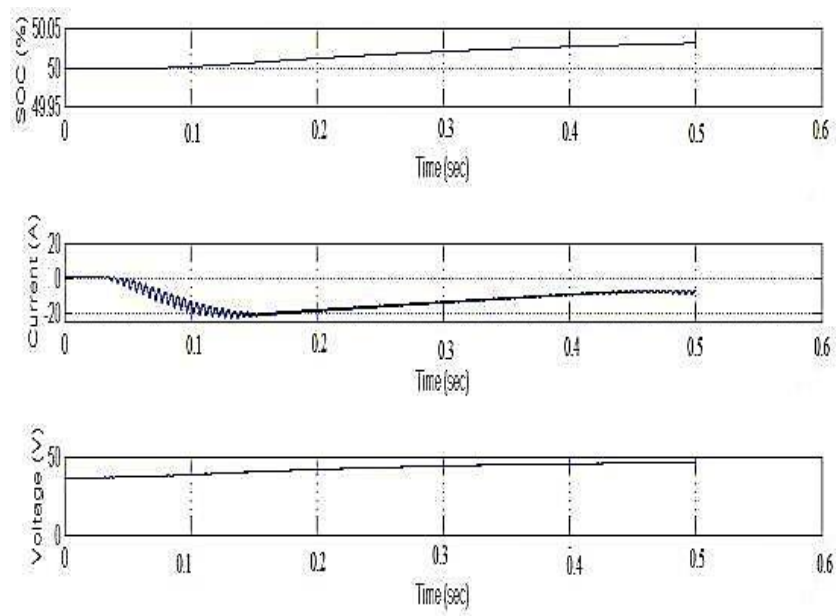

Fig.6. Battery Output Voltage $\mathrm{Vo}=42 \mathrm{~V}$ and Output current $I 0=16 \mathrm{~A}$ and $\mathrm{SOC} \%=50 \%$
The above Figure.6 shows the battery charging characteristics. The battery state of charge is $50 \%$ and the battery charges with output voltage of $42 \mathrm{~V}$ and current of 16A. Magnetizing inductance (maximum), $\mathrm{L}_{\mathrm{m}}$ (zvs), as given by Equation 13. Lm (max) is the max gain attained while the switching frequency is min, given by equation (14)

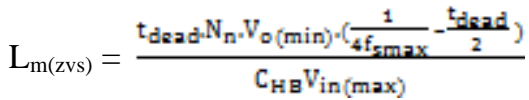

$L_{m(\max )}=L_{r(s c c)} \frac{\pi^{2}}{4} \frac{\frac{f_{e}}{f_{s, \text { min }}}-1}{1-\frac{1}{M_{d_{c} \text { max }}}}$

At last, the total inductance value is given by Equations 15 and 16.

$$
\begin{gathered}
\frac{1}{2}\left(\mathrm{~L}_{\mathrm{m}(\min )}+\mathrm{L}_{\mathrm{r}(\mathrm{scc})}\right) \mathrm{I}_{\mathrm{m}-\mathrm{pk}}^{2}>\frac{1}{2} \mathrm{C}_{\mathrm{HB}} \mathrm{V}_{\mathrm{in}(\max )}^{2} \\
\mathrm{I}_{\mathrm{m} \_\mathrm{pk}}=\frac{\mathrm{N}_{\mathrm{n}} \mathrm{V}_{\mathrm{o}[\mathrm{min})} \mathrm{T}_{\mathrm{g}}}{4 \mathrm{~L}_{\mathrm{m}}}
\end{gathered}
$$

\section{RESULTS AND DISCUSSIONS}

The presented work is simulated in MATLAB platform. The performance such as power facto and total harmonics distortion are discussed. The proposed method has better performance than the conventional method. The power has increased as 0.98 and harmonics has been reduced by 4.07 percentage.

Table 1. Performance comparison

\begin{tabular}{lll}
\hline Parameter & Conventional & Proposed \\
\hline Power factor & 0.91 & 0.98 \\
$\begin{array}{l}\text { THD of Input } \\
\text { current }\end{array}$ & $46.27 \%$ & $4.07 \%$
\end{tabular}

There exist numerous factors need to be considered while designing for the purpose of achieving max output voltage. Also, for studying the changing the factors.

\section{HARDWARE RESULTS}

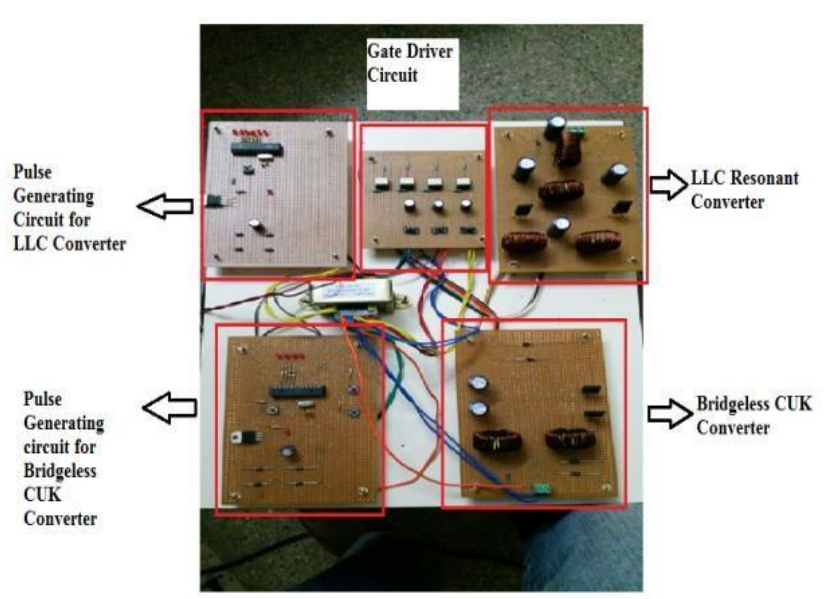

Fig.7. Hardware Setup

Published By: 


\section{LLC Resonant Tank based Converter for EV Charging Application}

The above Figure 7 shows the prototype of proposed converter which consists of Bridgeless CUK converter, LLC Resonant converter, Pulse generating circuit. The battery state of charge is $45 \%$ and the battery charges with output voltage of $40 \mathrm{~V}$ and current of 16A.

\section{CONCLUSION}

To increase the battery life the wide output voltage range LLC based tank methodology and also practical way of designing examination is conferred. By the use of LLC multi resonant tank circuit under low and high frequency current ripples are eliminated for electric vehicles. To attain unity power factor Bridgeless CUK converter is employed and power factor is improved by 0.99 . The dc output voltage of $42-24 \mathrm{~V}$ for $672 \mathrm{~W}$ is obtained from the modelling for EV application

\section{REFERENCES}

1. S. Chudjuarjeen, A. Sangswang, and C. Koompai, "An improved LLC resonant inverter for induction-heating applications with asymmetrical control," IEEE Trans. Ind. Electron., vol. 58, no. 7, Jul. 2011,pp. 2915-2925.

2. J.-Y. Lee, Yu-Seok Jeong, and B.-M. Han, "An isolated DC/DC converter using high-frequency unregulated LLC resonant converter for fuel cell applications," IEEE Trans. Ind. Electron., vol. 58, no. 7, pp. 2926-2934, Jul. 2011.

3. Y. C. Chuang, Y. L. Ke, H. S. Chuang, and Y. M. Chen, "Analysis and implementation of half-bridge series-parallel resonant converter for battery chargers," IEEE Trans. Ind. Appl., vol. 47, no. 1, Feb. 2011 pp. 258-270.

4. R. Beiranvand, B. Rashidian,M. R. Zolghadri, and S. M. H. Alavi, "Using LLC resonant converter for designing wide-range voltage source," IEEE Trans. Ind. Electron., vol. 58, no. 5, , May 2011pp. 1746-1756.

5. R. Beiranvand, B. Rashidian, M. R. Zolghadri, and S. M. H. Alavi, "Optimizing the normalized dead-time and maximum switching frequency of a wide-adjustable-range LLC resonant converter," IEEE Trans. Power Electron., vol. 26, no. 2, Feb. 2011, pp. 462-472.

6. R. Beiranvand, B. Rashidian, M. R. Zolghadri, and S. M. H. Alavi, "A design procedure for optimizing the LLC resonant converter as a wide output range voltage source," IEEE Trans. Power Electron., vol. 27, no. 8, Aug. 2012, pp. 3749-3763.

7. G. Ivensky, S. Bronshtein, and A. Abramovitz, “Approximate analysis of resonant LLC DC-DC converter," IEEE Trans. Power Electron., vol. 26, no. 11, Nov. 2011, pp. 3274-3284.

8. X. Fang, H. Hu, Z. J. Shen, and I. Batarseh, "Operation mode analysis and peak gain approximation of the LLC resonant converter," IEEE Trans. Power Electron., vol. 27, no. 4, Apr. 2012, pp. 1985-1995.

9. R. L. Steigerwald, "A comparison of half-bridge resonant converter topologies," IEEE Trans. Power Electron., vol. 3, no. 2, pp. 174-182, Apr. 1988.

10. H. Figge, T. Grote, N. Froehleke, J. Boecker, and P. Ide, "Paralleling of LLC resonant converters using frequency controlled current balancing," IEEE Power Electron. Spec. Conf., pp. 1080-1085, 2008.

11. B.-H. Lee, M.-Y. Kim, C.-E. Kim, K.-B. Park, and G.-W. Moon, "Analysis of LLC resonant converter considering effects of parasitic components," in Proc. 31st Int. Telecommun. Energy Conf., 2009, INTELEC, 2009, pp. 1-6.

\section{AUTHORS PROFILE}

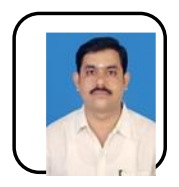

S. Nagaraj, he received Bachelor of Engineering degree in Electrical and Electronics Engineering from Bharathiyar University, India in 2004 and his Master of Engineering degree in Applied Electronics from Anna University, Chennai, India, in 2009. He is pursuing Ph.D. degree at St. Peter's Institute of Higher Education and Research, Chennai, India and also working as an Assistant Professor in P.B.College of Engineering. His current research interest includes Power Electronics and Drives.

R. Rani Hemamalini, she is serving in the field of teaching for the past 27 years at various levels. Presently she is working as Professor and Head, Department of Electrical and Electronics Engineering at St. Peter's Institute of Higher Education and Research, Avadi, Chennai, India. Her area of research includes Process controls and Instrumentation, Embedded System and VLSI. She has published more than 80 papers in the national/ international journals and conferences.

L. Rajaji, is a Professor in the Department of Electrical Engineering, ARM College of Engineering \& Technology, Chennai, India. He received Bachelor of Engineering from Madras University in 1997 and Master of

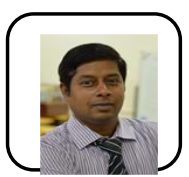
Engineering from The Maharaja Sayajirao University of Baroda, Vadadora, Gujarat, India in 2000. He has received Ph.D in the year 2010 from Sathyabama University, Chennai, India. His area of interest includes Distributed Power Generation, Power Electronics and Drives.

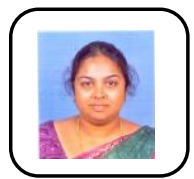

K. Srividya, she received her Bachelor of Engineering degree in Electronics and Communication Engineering and her Master Engineering degree in Applied Electronics in 2005 and 2009 respectively from Anna University,Chennai, India. Her current research interest includes Power Electronics Converters. She is presently working as an Assistant Professor at Sri Sairam Engineering College, Chennai, India

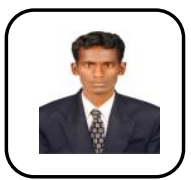

A. Mohandoss, he received Bachelor of Engineering degree in Electrical and Electronics Engineering Master of Engineering degree in Electrical Drives and Embedded Control in 2013 and 2015respectively from Anna University, Chennai, India. He is presently working as an Assistant Professor in P.B.College of Engineering. His current research interest includes Power Electronics Converters and drive system.

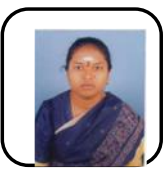

Retrieval Number: B3050129219/2020@BEIESP

DOI: 10.35940/ijeat.B3050.029320

Journal Website: www.ijeat.org
Published By:
Blue Eyes Intelligence Engineering \& Sciences Publication 